\title{
Academic Procrastination and Social Anxiety as Predictive Variables Internet Addiction of Adolescents
}

\author{
Zeliha Traş ${ }^{1} \&$ Gülden Gökçen ${ }^{1}$ \\ ${ }^{1}$ Education Faculty, Necmettin Erbakan University, Konya, Turkey \\ Correspondence: Zeliha Tras, Education Faculty, Necmettin Erbakan University, Konya, Meram Yeniyol 42090, \\ Turkey. E-mail: zztras@gmail.com
}

Received: March 31, 2020

Accepted: May 21, $2020 \quad$ Online Published: August 24, 2020

doi:10.5539/ies.v13n9p23

URL: https://doi.org/10.5539/ies.v13n9p23

\begin{abstract}
This study is aimed to examine the relationship between Internet addiction and academic procrastination and social anxiety. The study group of this research is 599 high school students, 239 (39.9\%) female, and $360(60.1 \%)$ male. It is for the Young Internet Addiction Scale, the Academic Procrastination Scale, and the Social Anxiety Scale for Adolescents. The data were analyzed by Pearson Correlation Analysis and Multiple Linear Regression Analysis techniques. According to the findings of the study, positive correlation between internet addiction and academic procrastination and social anxiety shows a significant relationship. In other findings of the study, it was found that academic procrastination and social anxiety predicted internet addiction. According to the findings, the most powerful predictor variable was academic procrastination. Expanding the number of samples in future researches, reaching students from the region and sociocultural level ensures that the findings can be generalized, and more reliable results are obtained.
\end{abstract}

Keywords: internet addiction, academic procrastination, social anxiety, adolescents

\section{Introduction}

Internet has become an important element with the responsibilities and needs of daily life on people in recent years (Ya \& Zhong, 2014). The use of the Internet is increasing in every area, which causes people to spend most of their time in front of the internet and disrupt their social duties (Güzel, 2006; Griffiths, Kuss, Billieux, \& Pontes, 2016). Increasing the time spent on the Internet can change people's feelings and thoughts (Koet al., 2012), it affects their attitudes, values, and communication methods in the process (Güzel, 2006). Looking at the main reason why the Internet affects life so much, it is easy and accessible to provide needs (Güzel, 2006; Ko et al., 2012), increasing the quality of life and well-being (Arslan, 2017), portable tablet and smartphones It is seen that it brings many benefits such as the use of telephones to carry out professional works (Ya \& Zhong, 2014). On the other hand, the misuse of technology (Beranuy, Oberst, Carbonell, \& Chamarro, 2009), behavioral control problem (Ya \& Zhong, 2014), emotional and intellectual imbalances caused by the excessive use of the internet (Griffiths, 2000; Odaci \& Çikrikçi, 2017) Common problems such as family, work, school life, and social life are also encountered. Internet, the ability to solve problems, provide the needs, and be up to date in life leads to an increase in usage (Aslan, 2019). While the rate of individuals using the internet was $72.9 \%$ in 2018 , this rate increased to $75.3 \%$ in 2019 (TÜİ, 2019) and the age range of the most users is 16-24 (TÜIK, 2019). When the evolution of Internet usage by gender, men in the 16-74 age group in Turkey, while $81.8 \%$ of the internet, it is disclosed that $68.9 \%$ of women (TUIK, 2019). The most common use of the internet is between the ages of 16-24 and coincidence with adolescence (Anlayisli \& Serin, 2017), the increase in internet use compared to previous years (TÜIK, 2019) makes it easier to start the addiction process in early ages (Cengizhan, 2005; Ceyhan, 2008; Doğan, 2013) and is considered as an important risk factor in the rapid development of addiction (Gürcan, 2010; Ögel, 2012; Taylan \& Işik, 2015). Due to the effects of the general development characteristics of adolescence on the individual (Arisoy, 2009; Cunningham, Gulliver, Farrer, Bennett, \& Carron-Arthur, 2014; Ögel, 2014; Machado, Bruck, Cat, Soares, \& Silva, 2018) focuses more attention on internet addiction, which is described as a kind of behavior problem and causes the formation of various psychological symptoms (Arisoy, 2009; Caplan, 2006; Çetin \& Ceyhan, 2014; Ögel, 2014; McCord, Rodebaugh, \& Levinson, 2014; Machado et al., 2018; Vries, Nakamae, Fukui, Denys, \& Narumoto, 2018; Tahiroğlu, Çelik, Bahali, \& Avci, 2010). When the literature is analyzed in the literature, it is stated that internet use triggers a high level of emotional loneliness in individuals (Odaci \& Kalkan, 2010) and low 
rates of positive emotions (Koç, 2017); shyness in adolescents (Ayas, 2012), loneliness (Batigün \& Hasta, 2010; Esen \& Siyez, 2011; Ümmet \& Ekşi, 2016), anxiety (Evren, Dalbudak, Evren, \& Çiftçi-Demirci, 2014; Jie et al., 2014) recently fear of missing developments in social settings (Tras \& Öztemel, 2019), state of violence (Yayan, Suna-Dağ, \& Düken, 2019), social appearance anxiety (Tras, Öztemel, \& Baltaci, 2019), depression (Cheung, Chan, Lui, Tsui, \& Chan, 2018), attempted suicide (Chang et al., 2015) There are studies showing that Also in other studies; sitting disorders, contractions and eye disorders in adolescents (Akbulut, 2013) insomnia, intense loss of will that occurs with the meaninglessness of life (Nalwa \& Anand, 2003), extreme fatigue (Lam, Peng, Mai, \& Jing, 2009), eating problems (Canan, 2016), weakening of the immune system (Cao \& Su, 2006), mental disorders (Kratzer \& Hegerl, 2008) decrease in working performance, academic failure (Yavuz, 2018) It was found that variables such as lack of self-confidence (Goel, Subramanyam, \& Kamath, 2013) were studied. In this study, the predictive relationships between internet addiction and academic procrastination and social anxiety factors were examined.

There are many studies in the literature that examine the relationship between internet addiction and academic procrastination. In his study, Can (2018) found that academic procrastination behavior is related to academic success level and time spent on the Internet. In Kim, Hong, Lee, and Hyun (2017), individuals who focus on the present tense are prone to poor self-control; this also increases internet addiction and procrastination; self-control of individuals who focus on the future is more robust; stated that these individuals have less risk of developing internet addiction and procrastination behavior. Hayat, Kojuri, and Amini (2020) in their studies, there was a positive relationship between internet addiction and academic procrastination; They explained that internet addiction negatively affects behaviors such as doing homework, studying for exams, following weekly reading assignments Similarly, procrastination can also be considered a common lack of self-regulation, as the tendency to voluntarily delay the onset or completion of the intended tasks (Sirois, 2016). Schouwenburg et al. (2004) consider procrastination as a motivation problem. In the studies of Li, Buxton, Kim, Haneuse, and Kawachi (2020), the behavior of procrastination has effects on sleep from primary motives; They stated that the symptoms of insomnia in adolescents are associated with the risk of being sleepy during the day. Ferrari and Díaz-Morales (2007) divide the procrastination behavior into two as academic and general procrastination. Academic procrastination; school-related duties and responsibilities are defined as anxiety caused by delaying academic tasks and jobs for various reasons or for no reason (Akdemir, 2013; Balkis, Erdinç, Buluş, \& Duru, 2006; Steel, 2007; Solomon \& Rothblum, 1984). General procrastination can be said to be perceived as part of the personality trait (Ferrari \& Díaz-Morales, 2007). At this point, it can be seen that academic procrastination negatively affects personality traits (Beck, Koons, \& Milgrim, 2000), time management (Shih, 2017), self-confidence (Batool, 2019) and motivation for success (Saddler \& Buley, 1999). There are also studies in the literature that both academic procrastination and general procrastination increase problematic internet usage (Günlü \& Ceyhan, 2017). Delay can be tiring to the person psycho-socially and stressful (Akdoğan \& Deniz, 2013; Sirois, 2016). These negative emotions that can be experienced can need adolescents' various procrastination behaviors and accelerate internet us e for academic reasons (Kawabe, Horiuchi, Ochi, Oka, \& Ueno, 2016). A study with adolescents' found that as their procrastination behavior decreased, internet addiction and depressive symptoms also decreased (Hernández, Ottenberger, Moessner, \& Ditzen, 2019). In the literature, students who have low academic achievement (Şaşmaz, 2013), who experience stress in working and achievement (Xin et al., 2018) attend schools (Durkee et al., 2012) the risk of internet addiction has been found to be high. In addition, many studies are similar to this situation (Goel, Subramanyam, \& Kamath, 2013). Gürültü (2016) found a positive significant relationship between social media addiction and academic procrastination and found that social media addiction explained about $19 \%$ of academic procrastination behavior. In recent researches; it has been observed that students who experience academic procrastination, feel academic anxieties, and have low self-regulation skills increase their problematic smartphone use (Yang, Asbury, \& Griffiths, 2019). The fact that students' time to use the internet affects their academic success is result from the fact that there is endless data on the internet and the benefits of the students in this direction, while their academic postponement consists of delaying their homework and tasks by spending free time on the internet. In addition, individuals who experience procrastination anxiety and low motivation, and individuals who develop general procrastination behavior and perfectionist behaviors, are found to be at higher risk of internet addiction (Malyshev \& Arkhipenko, 2019). On the other hand, in a study examining the increase of internet addiction and procrastination behavior together; self-control, social cohesion, and self-assessment skills were reported to be adversely affected (Geng, Han, Gao, Jou, \& Huang, 2018).

Social anxiety in the American Psychiatric Association (2013) diagnostic criteria reference handbook (DSM V, 2013) ".... a pronounced and constant fear of one or more social or action that may occur with unfamiliar people or others. Fear that the person will behave in a way that they will be humiliated or embarrassed". According to Beck and Emery (2006), social anxiety is an exaggerated fear of being the focus of attention and being negatively 
evaluated by another person or persons, and is considered worthless. Social anxiety generally begins during adolescence, if it is not taken into consideration, it can progress until adulthood and become a chronic course in one's life (Radtke, Strege, \& Ollendick, 2020). In adolescence, along with social anxiety reactions, the severity, resistance, duration of avoidance, and fear cause deterioration in the behavior of the individual, which makes life difficult (Biggs, Vernberg, \& Wu, 2012; Kartol \& Peker, 2020; Lee \& Stapinski, 2012). In a study examining the factors that cause social anxiety, a high relationship was found between increased peer victimization and decreased peer acceptance and social anxiety (Erath, Flanagan, \& Bierman, 2007). However, social anxiety may also cause fear of criticism, humiliation, and error during adolescence (Tassin, Reynaert, Jacques, \& Zdanowicz, 2014). In Klemanski, Curtiss, McLaughlin, and Nolen-Hoeksema (2017) studies, in adolescents with high levels of social anxiety and depression; It has been found that emotional awareness, emotion expression skills, and the use of emotion management strategies are adversely affected. In another study, in adolescents raised in a family environment that prevents the development of basic attitudes and competencies such as self-esteem or emotional regulation; social anxiety symptoms have been observed to increase (Gómez-Ortiz, Romera, Jiménez-Castillejo, Ortega-Ruiz, \& García-López, 2019). Adolescents who cannot develop positive interpersonal relationships and perceive the internet environment less threatening can meet their social relationship and interaction needs using the Internet (Ögel, 2014; Sappington, 2020; Zorbaz, 2013). In the literature, studies examining the relationship between internet addiction and social anxiety have increased considerably in recent years (Dong et al., 2019; Kiliç \& Durat, 2017; Tang, 2018; Yujia, Jiao, \& Liqiong, 2017). Thoughts that they will be humiliated or become ridiculous (Eldoğan, 2018), make it difficult to develop close sincere relationships (Tagay, Önen, \& Polat, 2018), decreases social skill acquisition (Glenn et al., 2019) and socialization in general can negatively affect the process (Karagün, Yildiz, Başaran, \& Çağlayan, 2010). When the findings in the literature are examined, it is understood that internet environments meet the trust needs of individuals with high social anxiety (Ögel, 2014). At the same time, in a study examining the social anxiety and psychological needs of adolescents with low internet addiction and high internet addiction, individuals with high internet addiction were found to have higher social anxiety than low ones (Canoğullari \& Güçray, 2017). In researches that may cause social anxiety; having interpersonal communication difficulties (Ceyhan, 2011; Ko et al., 2014; Lai et al., 2015), increased need for approval and approval on social networking sites (Weidman \& Levinson, 2015) emphasizes that factors such as low social skills, social competence and lack of empathy (Beidel et al., 2014) can turn the normal use of the Internet among adolescents into problematic use.

In terms of exposure to unlimited stimulants on the Internet, it is stated that individuals in adolescence are more vulnerable than adults and more unprotected than children (Anlayişli \& Serin, 2019). It is believed that academic procrastination and social anxiety, which are thought to be related to internet addiction during adolescence, when psychosocial development is critical, will contribute to related studies. Therefore, this study aimed to examine adolescents' relationship with internet addiction, academic procrastination, and social anxiety.

\section{Method}

\subsection{Research Model}

This study, which aims to examine the relationship between internet addiction, academic procrastination, and social anxiety in adolescents, is designed according to the quantitative method. This research, which examines the relationships between variables, was conducted according to the correlation survey model. Relational screening model is defined as a research model that aims to determine the degree and / or degree of co-variation between two or more variables (Shaughnessy, Zechmeister, \& Zechmeister, 2012).

\subsection{Study Group}

The study group of the research consists of 239 (39.9\%) girls and 360 (60.1\%) boys 599 students studying in high schools in the Mediterranean region in the 2019-2020 academic year. 260 students (43.3\%) attend 9th grade, 151 $(25.3 \%)$ attend 10th grade, $93(15.5 \%)$ attend 11 th grade and $95(15.8 \%)$ attend 12 th grade. An easily accessible sampling method was used as the sampling method.

\subsection{Materials}

\subsubsection{Young Internet Addiction Short Form}

Young internet addiction test short form, developed by Young (1998) and adapted to the short form by Pawlikowski, Altstötter-Gleic, and Brand (2013), consists of 12 items. Five-point Likert ( $1=$ Never, $5=$ Always) is a type scale. There are no items to be scored in reverse in the scale. A high score on the scale indicates that the individual's internet addiction level is high. Adaptation of the scale to Turkish and its validity and reliability study were performed by Kutlu et al. (2016). Cronbach alpha coefficient obtained in the reliability study of Young 
Internet Addiction Test Short Form was found to be 0.91 in university students and 0.86 in adolescents (Kutlu, Savci, Demir, \& Aysan, 2016). The reliability Cronbach alpha coefficient of the scale for this study was calculated as 0.79 .

\subsubsection{Academic Procrastination Scale}

Scale; It consists of 19 expressions including 12 negative and 7 positive, which includes the tasks that students are responsible for doing in their educational life (such as studying, preparing for exams, preparing projects). The responses to the statements in this scale are rated as 5-point Likert type, with "never reflect me" and "reflect me completely". The highest score that can be obtained from the scale is 95 , the lowest score is 19 . The high score obtained from the scale shows that students are academic postponers. The Cronbach alpha coefficient obtained in the reliability study of the academic procrastination scale was found to be 0.92 (Çakici, 2003). The reliability Cronbach alpha coefficient of the scale for this study was calculated as 0.88 .

\subsubsection{Social Anxiety Scale for Adolescents}

The Turkish version of the Social Anxiety Scale for Adolescents was carried out by Aydin and Sütçü (2007), which was developed by La Greca and Lopez (1998). The items in the scale include expressions between "never" and "always" as 5 points Likert. While the highest score that the individuals who answered the scale can get from the scale is 90 , the lowest score is 18 . High scores are an indication that social anxiety is more. The Cronbach alpha coefficient obtained in the reliability study of the scale was found to be 0.88 (Aydin \& Sütçü, 2007). The reliability Cronbach alpha coefficient of the scale for this study was calculated as 0.91 .

\subsubsection{Data Collection}

Data collection was carried out by face-to-face interview method in the classroom environment with the permission of school administrations. It was explained that the participation form was on a voluntary before the scale form was distributed to the students. It took students about 25 minutes to complete the scale form.

\subsection{Data Analysis}

In the analysis of the data, it was first examined whether there was missing data and it was determined that there was no missing data in the variable set. The research data were analyzed using the SPSS (24) program. Pearson Moments Product Correlation Technique was applied to determine the relationship between the participants' internet addiction, academic procrastination and, social anxiety variables. Also, for the analysis of the data, multiple linear regression, which is the analysis for predicting the dependent variable based on two or more independent variables (academic procrastination and social anxiety) associated with the dependent variable (internet addiction), was used. While the extreme data was extracted in the research, Cook's, Leverage Values and Mahalanobis values were examined and 1 data determined were extracted. Therefore, the analysis of the data was done over 599 people. The skewness and kurtosis coefficients were then checked to determine whether the scores from the relevant scales meet the normal distribution. Skewness and Kurtosis coefficients of Internet Addiction, Academic Procrastination, and Social Anxiety Scales are between -1 and +1 . If the Skewness and Kurtosis coefficients are between -1 and +1 , the distribution is assumed to be normal (Hair, Black, Babin, Anderson, \& Tatham, 2006). The kurtosis and distortion values of the variables are given in table-1.

\section{Results}

\subsection{Descriptive Statistics and Relations of Variables}

Table 1. Descriptive statistics for variables $(\mathrm{N}=599)$

\begin{tabular}{cccccccc}
\hline Scales & $\mathrm{N}$ & Min & Max & Average & Standard Deflection & Skewness & Kurtosis \\
\hline Internet Addiction & 599 & 12 & 53 & 27.17 & 7.51802 & .469 & .188 \\
Akademic Procrastination & 599 & 19 & 84 & 48.23 & 12.28111 & .365 & -.018 \\
Social Anxiety & 599 & 18 & 85 & 39.51 & 13.628884 & .701 & .209 \\
\hline
\end{tabular}

In Table 1, the average of internet addiction score is 27.27; the average of academic procrastination score 48.23; social anxiety mean score of adolescents is 39.51 . 
Table 2. Correlation analysis results regarding variables

\begin{tabular}{lccc}
\hline Variables & 1 & 2 & 3 \\
\hline 1. İnternet Addiction & - & & \\
2. Akademic Procrastination & $.46^{* *}$ & - & \\
3. Social Anxiety & $.21^{* *}$ & - & - \\
\hline
\end{tabular}

Note. ${ }^{* * \mathrm{p}<.01}$.

According to the results of the research in Table 2, a positive correlation was found between internet addiction scores and academic procrastination scores $(\mathrm{r}=.46 ; \mathrm{p}<.01)$. There is no significant relationship between academic procrastination and social anxiety. Also, a significant positive correlation was found between internet addiction scores and social anxiety scores $(\mathrm{r}=.21 ; \mathrm{p}<.01)$.

\subsection{Academic Procrastination and Social Anxiety Predict Internet Addiction}

In the research, multiple regression analysis was carried out to determine the predictability of academic procrastination and social anxiety in internet addiction. Findings obtained as a result of the analysis are presented in Table 3.

Table 3. Regression analysis results on the prediction of academic procrastination and social anxiety in internet addiction

\begin{tabular}{ccccccc}
\hline & Variables & $\mathrm{B}$ & $\mathrm{SE}$ & $\beta$ & $\mathrm{T}$ & $\mathrm{p}$ \\
\cline { 2 - 7 } & Stable & 9.738 & 1.281 & & 7.603 & 0.00 \\
& Akademic Procrastination & .278 & .022 & .455 & 12.816 & 0.00 \\
Social Anxiety & .101 & .020 & .184 & 5.174 & 0.00 \\
\hline
\end{tabular}

Note. $\mathrm{R}=.50, \mathrm{R}^{2}=.25 ; \mathrm{F}_{(2-596)}=101.339, \mathrm{p}<.001$

According to the regression analysis results in Table 3 , academic procrastination scale scores $(\beta=.45, \mathrm{p}<.001, \mathrm{t}=$ 12.816), social anxiety scale scores $(\beta=.18, \mathrm{p}<.001, \mathrm{t}=5.174)$ internet addiction scale scores seem to be significant predictors. Looking at the relevant $t$ values, it is seen that the strongest predictive variable is academic procrastination $(\mathrm{t}=12.816, \mathrm{p}<.001)$. Then it is seen that social anxiety $(\mathrm{t}=5.174, \mathrm{p}<.001)$. It also explains about $25 \%$ of the total variance related to academic procrastination and social anxiety internet addiction.

\section{Discussion}

In this study, a positive correlation was found between adolescents' internet addictions and academic procrastination $(\mathrm{r}=.46, \mathrm{p}<0.01)$. As Internet addiction increases, academic procrastination also increases. This result supports the research results in the literature (Custer, 2016: 48; Demir \& Kutlu, 2017; Kandemir, 2014; Kindt, Szász-Janocha, Rehbein, \& Lindenberg, 2019; Wretschko, 2006). Similar to the findings of this research, there are positively significant relationships between students' facebook attitudes, internet usage history and daily internet usage time (Akdemir, 2013), social media addiction (Gürültü, 2016), and academic procrastination tendencies. However, in another study examining the effect of internet addiction of university students on academic procrastination, there is a negative relationship between academic procrastination and internet addiction (Yurdakoş \& Biçer, 2019). Academic procrastination is generally described as adolescents' failure to perform school-related tasks in a timely manner (Akdemir, 2013), adolescents increasingly taking refuge in the virtual world (Aslan, 2019), a possible reason for a positive relationship between internet addiction and academic procrastination. can be considered as.

Another finding in the study is that one of the significant predictors of internet addiction is academic procrastination $(\mathrm{p}=.000)$. Studies in the literature support that one of the significant predictors of internet addiction is academic procrastination (Uzun, Önal, \& Tokel, 2014). In addition, Yang, Asbury, and Griffiths (2018) found that problematic smartphone use is a significant predictor of academic procrastination and academic anxiety. Erdogan, Pamuk, Eren-Yuruk, and Pamuk (2013) found that mobile phone addiction is also an important predictor of academic procrastination. The situations that may lead to postponement such as lack of self-regulation skills (Bojuwoye, 2019), not improving the ability of working control in the academic field (Balkis et al., 2006) and having difficulty in decision making (Uzun, 2009) also tend to usage of internet, It can be said that it increased. In addition to these, the results that may support postponement such as imbalance in behavior, control and planning impulses that may develop as a result of uncontrolled use of the internet, and forward thinking abilities (Casey, 
Tottenham, Liston, \& Durston, 2005); It can turn internet usage (Tarhan, 2012) into dependence, where the individual can experience intense feeling of control. In addition, internet addiction may be a factor that makes it easier for the individual to delay their vital responsibilities (Sahin, 2014). Because while the individual can turn the internet into an escape environment against stressful situations, unwanted emotions (Jun, 2017; Tokunaga \& Rains, 2010), he is expected to develop methods to cope when he encounters such situations in real life (Demir, 2019). Researches show that as adolescents' academic procrastination increases, strategies to cope with stress in real life decrease (Cerit, 2019; Hamaideh, 2011). Giving individuals jobs, duties, and responsibilities that they cannot lift in real life can also cause academic procrastination (Quinn, 2019). It is thought that academic procrastination is an important determinant in the formation of behavioral and psychological problems that may prevent students from showing their talents, real performances (Balkis \& Duru, 2009).

There are studies supporting the fact that adolescents spend more time on the Internet to get rid of social anxiety, which increases internet addiction (Kalecik, 2016; Weinstein et al., 2015; Young \& Lo, 2012; Yilmaz, Ali \& Civan, 2015). However, as a result of this study, a positive relationship was found between internet addiction and social anxiety. According to this, as internet addiction increases, social anxiety is also found to increase $(\mathrm{r}=.21, \mathrm{p}<$ 0.01). Internet use, avoiding worrying situations in adolescents (Sela, Zach, Amichay-Hamburger, Mishali, \& Omer, 2020), fear of embarrassment (Tian et al., 2019), moving away from tension and discomfort experienced in not being able to adapt to different social positions (Cheung et al., 2018) can be considered as an option in providing. However, social anxiety does not only accept the evaluation of individuals in social settings, individuals may feel anxiety about evaluation in the internet environment (Beck, 2005). Anlayişli and Serin (2019) in study, they stated that individuals with high social anxiety had high levels of internet addiction. The result of this study supports the participants' anxiety in the internet environment.

Another finding of the research is that one of the significant predictors of internet addiction is social anxiety (p $=.000$ ). Studies in the literature support that one of the significant predictors of internet addiction is social anxiety (Yen, King, \& Tang, 2010; Yen et al., 2007). This result is also supported by studies that adolescents increase the susceptibility to social addiction (Akboğa \& Gürgan, 2019; Caplan, 2006; Ko et al., 2014; Lai et al., 2015; Yen et al., 2012). However, there are studies in which social anxiety is not a significant predictor of internet addiction (Douglas, 2016). As internet addiction increases, social relationships and social cohesion can be said to get slow down. (Ögel, 2014; McIntyre, Wiener, \& Saliba, 2015). Yen et al. (2012) explained that adolescents experience less social anxiety on the internet compared to social environments, and the internet may cause addiction in individuals with social anxiety when used intensely to harm vital functionality. In this case, the internet environment is also a part of the world and it can be said that it is filled with life by real people (Ögel, 2014) It also points out that individuals with social anxiety will provide an important basis for addiction (Xin et al., 2018).

\section{Conclusion and Suggestions}

Due to the fact that Internet addiction behavior keeps its agenda increasing and refreshing, expanding the number of samples in future researches, reaching students from every region and sociocultural level can provide generalization of findings and obtain more reliable results.

In addition to quantitative techniques, qualitative data collection techniques such as semi-structured interview forms, case studies, focus group interviews can be used. Since this study is a cross-sectional study, when the conditions such as education level, development period, development tasks, socio-economic level of the study group in which the study group changes, there are limitations in the evaluation of the internet addiction level, academic proscrastination and social anxiety in terms of cause and effect. To reveal the cause-effect relationship, a) longitudinal data can be used or b) experimental studies can be carried out (Büyüköztürk et al., 2017).

\section{References}

Akboğa, Ö. F., \& Gürgan, U. (2019). Gençlerde internet bağimliliği ile sosyal kaygi bozukluğu arasindaki ilişkinin yaşam doyumu ve bazi değişkenler açisindan incelenmesi. Avrasya Sosyal ve Ekonomi Araştirmalari Dergisi, 6(6), 443-464. Retriewed from https://dergipark.org.tr/en/pub/asead

Akbulut, Y. (2013). Çocuk ve ergenlerde bilgisayar ve internet kullaniminin gelişimsel sonuçlari. Trakya Üniversitesi Ĕ̈itim Fakültesi Dergisi, 3(2), 53-68.

Akdemir, T. N. (2013). Illköğretim Öğrencilerinin Facebook Tutumlari ile Akademik Erteleme Davranişlari ve Akademik Başarilari Arasindaki İlişkilerin Incelenmesi. Yayimlanmamiş Yüksek Lisans Tezi, İstanbul: Marmara Üniversitesi FBE.

Akdoğan, A., \& Deniz, M. (2013). Farkli depresyon anksiyete stres düzeylerine sahip üniversite öğrencilerinin akademik erteleme davranişlarinin incelenmesi (Master's thesis, Necmettin Erbakan Üniversitesi). 
Anlayişli, C., \& Serin, N. B. (2019). Lise Öğrencilerinde İnternet Bağimliliği ve Depresyonun Cinsiyet, Akademik Başari ve İnternete Giriş Süreleri Açisindan İncelenmesi. Folklorledebiyat, 25(97), 730-743. https://doi.org/10.22559/folklor.977

Antony, M. M., \& Swinson, R. P. (2000). The shyness \& social anxiety workbook: Proven techniques for overcoming your fears. New Harbinger Publications.

Arisoy, Ö. (2009). İnternet bağimliliği ve tedavisi. Psikiyatride güncel yaklaşimlar, 1(1), 55-67.

Arslan, G. (2017). Psychological maltreatment, forgiveness, mindfulness, and internet addiction among young adults: A study of mediation effect. Computer in Human Behavior, 72, 57-66. https://doi.org/10.1016/j.chb.2017.02.037

Aslan, N. (2019). Ergenlerde internet bağimliliği, yayginliği, nedenleri ve sonuçlari üzerine bir araştirma. Journal of International Social Research, 12(65). https://doi.org/10.17719/jisr.2019.3506

Ayas, T. (2012). The relationship between internet and computer game addiction level and shyness among highschool students. Educational Sciences: Theory \& Practise, 12(2), 632-636.

Aydin, A., \& Sütcü, S. T. (2007). Ergenler için sosyal kaygi ölçeğinin (ESKÖ) geçerlik ve güvenirliğinin incelenmesi. Çocuk ve Gençlik Ruh Să̆liği Dergisi, 14(2), 79-89.

Balkis, M., \& Duru, E. (2009). Akademik Erteleme Davranişinin Öğretmen Adaylari Arasindaki Yayginliği, Demografik Özellikler ve Bireysel Tercihlerle İlişkisi. Çanakkale Onsekiz Mart Üniversitesi Ĕgitim Fakültesi Araştirma Dergisi, 5(1), 18-32.

Balkis, M., Duru, E., Buluş, M., \& Duru, S. (2006). Üniversite Öğrencilerinde Akademik Erteleme Eğiliminin Çeşitli değişkenler Açisindan İncelenmesi. Ege Eğitim Dergisi, 7(2), 57-73. Retrieved from https://dergipark.org.tr/tr/pub/egeefd/issue/4915/67280

Batigün, A. D., \& Hasta, D. (2010). Internet bağimliliği: Yalnizlik ve kişilerarasi ilişki tarzlari açisindan bir değerlendirme. Anadolu Psikiyatri Dergisi, 11(3), 213-219.

Batool, S. S. (2019). Academic achievement: Interplay of positive parenting, self-esteem, and academic procrastination. Australian Journal of Psychology. https://doi.org/10.1111/ajpy.12280

Beck, A. J. (2005). Bilişsel Terapi ve Duygusal Bozukluklar. çev. Veysel Öztürk, Aysun Türkcan. Ankara: Litera Yayincilik.

Beck, B. L., Koons, S. R., \& Milgrim, D. L. (2000). Correlates and consequences of behavioral procrastination: The effects of academic procrastination, self-consciousness, self-esteem and self-handicapping. Journal of social behavior and personality, 15(5), 3 .

Beck, T. A., \& Emery, G. (2006). Anksiyete bozukluklari ve fobiler bilişsel bir bakiş açisi (Çev: Veysel Öztürk). İstanbul: Litera Yayicilik (pp. 21-38).

Beidel, D. C., Alfano, C. A., Kofler, M. J., Rao, P. A., Scharfstein, L., \& Sarver, N. W. (2014). The impact of social skills training for social anxiety disorder: A randomized controlled trial. Journal of Anxiety Disorders, 28(8), 908-918. https://doi.org/10.1016/j.janxdis.2014.09.016

Beranuy, M., Oberst, U., Carbonell, X., \& Chamarro. (2009). Problematic internet and mobile phone use and clinical symptoms in college students: The role of emotional intelligence. Computers in Human Behavior, 25, 1182-1187. https://doi.org/10.1016/j.chb.2009.03.001

Biggs, B. K., Vernberg, E. M., \& Wu, Y. P. (2012). Social anxiety and adolescents' friendships: The role of social withdrawal. The Journal of Early Adolescence, 32(6), 802-823. https://doi.org/10.1177/0272431611426145

Bojuwoye, O. (2019). Causes of Academic Procrastination Among High School Pupils with Learning Disabilities in Ilorin, Kwara State, Nigeria. https://doi.org/10.20533/ijtie.2047.0533.2019.0171.

Büyüköztürk, Ş., Çakmak, Ş. K., Akgün, Ö. E., Karadeniz, Ş., \& Demirel, F. (2017). Bilimsel araştirma yöntemleri. Ankara: Pegem Yayinlari. https://doi.org/10.14527/9789944919289

Can, S. (2018). Ergenlerin Akademik erteleme davranişlari, internet bağimliliği ve temel psikolojik ihtiyaçlari: bir model önerisi. Yüksek Lisans Tezi. Yildiz Teknik Üniversitesi.

Canan, F. (2016). The relationship between internet addiction and eating disorders. Eating and Weight Disorders-Studies on Anorexia, Bulimia and Obesity, 21(1), 137-138. https://doi.org/10.1007/s40519-015-0203-2 
Canoğullari, Ö., \& Güçray, S. S. (2017). İnternet bağimlilik düzeyleri farkli ergenlerin cinsiyetlerine göre psikolojik ihtiyaçlari, sosyal kaygilari ve anne baba tutum algilarinin incelenmesi. Journal of the Cukurova University Institute of Social Sciences, 26(1).

Cao, F. \& Su, L. (2006). Internet Addiction Among Chinese Adolescents: Prevalence and Psychological Features. Child: Care, Health and Development, 33(3), 275-281. https://doi.org/10.1111/j.1365-2214.2006.00715.x

Caplan, S. E. (2006). Relations among loneliness, social anxiety, and problematic Internet use. CyberPsychology \& behavior, 10(2), 234-242. https://doi.org/10.1089/cpb.2006.9963

Casey, B., Tottenham, N., Liston, C., \& Durston, S. (2005). Imaging the developing brain: what have we learned about cognitive development? Trends in cognitive sciences, 9(3), 104-110. https://doi.org/10.1016/j.tics.2005.01.011

Cengizhan, C. (2005). Öğrencilerin bilgisayar ve internet kullaniminda yeni bir boyut: "Internet bağimliliği”. Marmara Üniversitesi Atatürk Ĕgitim Fakültesi Eğitim Bilimleri Dergisi, 22(22), 83-98.

Cerit, H. (2019). Lise ögrencilerinin stresle başa çikma tarzlariyla akademik erteleme ve genel erteleme düzeyleri arasindaki ilişkinin incelenmesi.Yüksek Lisans Tezi. Marmara Ünversitesi.

Ceyhan, A. A. (2011). İnternet kullanma temel nedenlerine göre üniversite öğrencilerinin problemli internet kullanimi ve algiladiklari iletişim beceri düzeyleri. Kuram ve Uygulamada Eğitim Bilimleri, 11(1), 59-77.

Ceyhan, E. (2008). Ergen ruh sağliği açisindan bir risk faktörü: İnternet bağimliliği. Çocuk ve Gençlik Ruh Sağliği Dergisi, 15(2).

Chang, F.-C., Chiu, C.-H., Miao, N.-F., Chen, P.-H., Lee, C.-M., Chiang, J.-T., \& Pan, Y.-C. (2015). The relationship between parental mediation and Internet addiction among adolescents, and the association with cyberbullying and depression. Comprehensive psychiatry, 57, 21-28. https://doi.org/10.1016/j.comppsych.2014.11.013

Cheung, J. C.-S., Chan, K. H.-W., Lui, Y.-W., Tsui, M.-S., \& Chan, C. (2018). Psychological Well-Being and Adolescents' Internet Addiction: A School-Based Cross-Sectional Study in Hong Kong. Child and adolescent social work journal, 35(5), 477-487. https://doi.org/10.1007/s10560-018-0543-7

Cunningham, J. A., Gulliver, A., Farrer, L., Bennett, K., \& Carron-Arthur, B. (2014). Internet interventions for mental health and addictions: current findings and future directions. Current psychiatry reports, 16(12), 521. https://doi.org/10.1007/s11920-014-0521-5

Custer, N. R. (2016). Test anxiety and academic procrastination among pre-licensure nursing students (Doctoral dissertation, Indiana University of Pennsylvania).

Çakici, D. Ç. (2003). Lise ve üniversite öğrencilerinde genel erteleme ve akademik erteleme davranişinin incelenmesi (Unpublished master thesis). Ankara: Ankara Üniversitesi, Eğitim Bilimleri Enstitüsü.

Çetin, B. A., \& Ceyhan, A. A. (2014). Ergenlerin internette kimlik denemeleri ve problemli internet kullanim davranişlari. The Turkish Journal on Addictions, 1(2), 5-46. https://doi.org/10.15805/addicta.2017.4.1.0016

De Vries, H. T., Nakamae, T., Fukui, K., Denys, D., \& Narumoto, J. (2018). Problematic internet use and psychiatric co-morbidity in a population of Japanese adult psychiatric patients. BMC psychiatry, 18(1), 9. https://doi.org/10.1186/s12888-018-1588-z

Demir, M. (2019). Lise ögrrencilerinin problem çözme becerileri, algilanan stres ve yaşam doyumu düzeyleri arasindaki ilişsinin incelenmesi (Master's thesis, İstanbul Sabahattin Zaim Üniversitesi, Sosyal Bilimler Enstitüsü, Eğitim Bilimleri Anabilim Dali).

Demir, Y., \& Kutlu, M. (2017). İnternet bağimliliği, akademik erteleme ve akademik başari arasindaki ilişkiler. The Journal of Academic Social Science Studies, 61, 91-105. https://doi.org/10.9761/JASSS7296

Dilbaz, N. (1997). Sosyal fobi. Psikiyatri Dünyasi, 1(1), 18-24.

Doğan, A. (2013). Internet bağimliliği yayginliği (Doctoral dissertation, DEÜ Eğitim Bilimleri Enstitüsü).

Dong, B., Zhao, F., Wu, X. S., Wang, W. J., Li, Y. F., Zhang, Z. H., \& Sun, Y. H. (2019). Social anxiety may modify the relationship between internet addiction and its determining factors in Chinese adolescents. International Journal of Mental Health and Addiction, 17(6), 1508-1520. https://doi.org/10.1007/s11469-018-9912-x

Douglas, J. (2016). Personality traits, social anxiety levels, and stress coping mechanisms as predictors of Internet use among adults. Retrieved from http://hdl.handle.net/10788/3119 
DSM V. (2013). APA tani ölçütleri başvuru kitabi (E. Köroğlu, Çev.). Ankara: Hekimler Yayin Birliği.

Durkee, T., Kaess, M., Carli, V., Parzer, P., Wasserman, C., Floderus, B., ... Bobes, J. (2012). Prevalence of pathological internet use among adolescents in E urope: demographic and social factors. Addiction, 107(12), 2210-2222. https://doi.org/10.1111/j.1360-0443.2012.03946.x

Eldoğan, D. (2018). Sosyal anksiyete bozukluğunun alt tipleri: Heterojen bir tani kategorisi. Psikiyatride Güncel Yaklaşimlar, 10(2), 202-217. https://doi.org/10.18863/pgy.358102

Erath, S. A., Flanagan, K. S., \& Bierman, K. L. (2007). Social anxiety and peer relations in early adolescence: Behavioral and cognitive factors. Journal of Abnormal Child Psychology, 35(3), 405-416. https://doi.org/10.1007/s10802-007-9099-2

Erdoğan, U., Pamuk, M., Eren-Yürük, S., \& Pamuk, K. (2013). Academic procrastination and mobile phone. In International Academic Conference on Education, Teaching and E-learning.

Esen, E., \& Siyez, D. M. (2011). An investigation of psycho-social variables in predicting internet addiction among adolescents. Türk Psikolojik Danişma ve Rehberlik Dergisi, 4(36), 127-136.

Evren, C., Dalbudak, E., Evren, B., \& Ciftci-Demirci, A. (2014). High risk of internet addiction and its relationship with lifetime substance use, psychological and behavioral problems among 10th grade adolescents. Psychiatria Danubina, 26(4).

Ferrari, J. R., \& Díaz-Morales, J. F. (2007). Procrastination: Different Time Orientations Reflect Different Motives. Journal of Research in Personality, 41, 707-714. https://doi.org/10.1016/j.jrp.2006.06.006

Geng, J., Han, L., Gao, F., Jou, M., \& Huang, C. C. (2018). Internet addiction and procrastination among Chinese young adults: A moderated mediation model. Computers in Human Behavior, 84, 320-333. https://doi.org/10.1016/j.chb.2018.03.013

Glenn, L. E., Keeley, L. M., Szollos, S., Okuno, H., Wang, X., Rausch, E., ... \& Augenstein, T. M. (2019). Trained observers' ratings of adolescents' social anxiety and social skills within controlled, cross-contextual social interactions with unfamiliar peer confederates. Journal of Psychopathology and Behavioral Assessment, 41(1), 1-15. https://doi.org/10.1007/s10862-018-9676-4

Goel, D., Subramanyam, A., \& Kamath, R. (2013). A study on the prevalence of internet addiction and its association with psychopathology in Indian adolescents. Indian Journal of Psychiatry, 55(2), 140. https://doi.org/10.4103/0019-5545.111451

Gómez-Ortiz, O., Romera, E. M., Jiménez-Castillejo, R., Ortega-Ruiz, R., \& García-López, L. J. (2019). Parenting practices and adolescent social anxiety: A direct or indirect relationship? International Journal of Clinical and Health Psychology, 19(2), 124-133. https://doi.org/10.1016/j.jichp.2019.04.001

Griffiths, M. D. (2000). Internet addiction-Time to be taken seriously? Addiction Research, 8, 413-418. https://doi.org/10.3109/16066350009005587

Griffiths, M. D., Kuss, D. J., Billieux, J., \& Pontes, H. M. (2016). The evolution of internet addiction: A global perspective. Addictive Behaviors, 53, 193-195. https://doi.org/10.1016/j.addbeh.2015.11.001

Günlü, A., \& Ceyhan, A. A. (2017). Ergenlerde internet ve problemli internet kullanim davranişinin incelenmesi. The Turkish Journal on Addictions (ADDICTA), 75-117. http://dx.doi.org/10.15805/addicta.2017

Gürcan, N. (2010). Ergenlerin problemli internet kullanimlari ile uyumlari arasindaki ilişskinin incelenmesi (Doctoral dissertation, Selçuk Üniversitesi Eğitim Bilimleri Enstitüsü).

Gürültü, E. (2016). Lise öğrencilerinin sosyal medya bağimliliklari ve akademik erteleme davranişlari arasindaki ilişkinin incelenmesi. Retrieved from https://www.researchgate.net/publication/322487804

Güzel, M. (2006). Küreselleşme, internet ve gençlik kültürü. Küresel İletişim Dergisi, 1, 1-16.

Hair, J. F., Black, W. C., Babin, B. J., Anderson, R. E., \& Tatham, R. L. (2006). Multivariate data analysis. New Jersey: Hoboken.

Hamaideh, S. H. (2011). Stressors and Reactions to Stressors Among University Students. International Journal of Social Psychiatry, 57(1), 69-80. https://doi.org/10.1177/0020764010348442

Hayat, A. A., Kojuri, J., \& Amini, M. (2020). Academic procrastination of medical students: The role of Internet addiction. Journal of advances in medical education \& professionalism, 8(2), 83-89. https://doi.org/10.30476/JAMP.2020.85000.1159 
Hernández, C., Ottenberger, D. R., Moessner, M., Crosby, R. D., \& Ditzen, B. (2019). Depressed and swiping my problems for later: The moderation effect between procrastination and depressive symptomatology on internet addiction. Computers in Human Behavior, 97, 1-9 https://doi.org/10.1016/j.chb.2019.02.027

Jie, T., Yizhen, Y., Yukai, D., Ying, W., Dongying, Z., \& Jiaji, W. (2014). Prevalence of internet addiction and its association with stressful life events and psychological symptoms among adolescent internet users. Addictive Behaviors, 39, 744-747. https://doi.org/10.1016/j.addbeh.2013.12.010

Jun, W. (2017). An analysis work on correlation of internet addiction and school age groups. Cluster Computing, 20(1), 879-882. https://doi.org/10.1007/s10586-016-0693-3

Kalecik, S. (2016). Problemli internet ve akilli telefon kullanimina ilişkin olarak duygu düzenleme, öz-denetim, yenilik arayişi, depresyon ve sosyal kaygi semptomlari. Bahçeşehir Üniversitesi, İstanbul.

Kandemir, M. (2014). A model explaining academic procrastination behavior. Pegem Eğitim ve Öğretim Dergisi, 4(3), 51-72. https://doi.org/10.14527/pegegog.2014.016

Karagün, E., Yildiz, M., Başaran, Z., \& Çağlayan, Ç. (2010). Sosyal fobi özellikleri gösteren üniversite öğrencilerinde rekreatif aktivitelerin fobik tutumlar üzerine etkisinin araştirilmasi. Anadolu Psikiyatri Dergisi, 11, 139-144.

Kartol, A., \& Peker, A. (2020). Ergenlerde Sosyal Ortamlarda Gelişmeleri Kaçirma Korkusu (Fomo) Yordayicilarinin İncelenmesi. OPUS Uluslararasi Toplum Araştirmalari Dergisi, 15(21), 1-1. https://doi.org/10.26466/opus.628081

Kawabe, K., Horiuchi, F., Ochi, M., Oka, Y., \& Ueno, S. I. (2016). Internet addiction: Prevalence and relation with mental states in adolescents. Psychiatry and clinical neurosciences, 70(9), 405-412. https://doi.org/10.1111/pcn.12402

Kiliç, Z., \& Durat, G. (2017). Üniversite Öğrencilerinde Problemli İnternet Kullaniminin Genel Psikolojik Belirtileri ve Sosyal Fobi ile İlişkisi. Sakarya Tip Dergisi, 7(2), 97-104. https://doi.org/10.31832/smj.332753

Kim, J., Hong, H., Lee, J., \& Hyun, M. H. (2017). Effects of time perspective and self-control on procrastination and Internet addiction. Journal of behavioral addictions, 6(2), 229-236. https://doi.org/10.1556/2006.6.2017.017

Kindt, S., Szász-Janocha, C., Rehbein, F., \& Lindenberg, K. (2019). School-related risk factors of internet use disorders. International journal of environmental research and public health, 16(24), 4938. https://doi.org/10.3390/ijerph16244938

Klemanski, D. H., Curtiss, J., McLaughlin, K. A., \& Nolen-Hoeksema, S. (2017). Emotion regulation and the transdiagnostic role of repetitive negative thinking in adolescents with social anxiety and depression. Cognitive therapy and research, 41(2), 206-219. https://doi.org/10.1007/s10608-016-9817-6

Ko, C. H., Liu, T. L., Wang, P. W., Chen, C. S., Yen, C. F., \& Yen, J. Y. (2014). The exacerbation of depression, hostility, and social anxiety in the course of Internet addiction among adolescents: A prospective study. Comprehensive Psychiatry, 55(6), 1377-1384. https://doi.org/10.1016/j.comppsych.2014.05.003

Ko, C. H., Yen, J. Y., Yen, C. F., Chen, C. S., \& Chen, C. C. (2012). The association between Internet addiction and psychiatric disorder: a review of the literature. European Psychiatry, 27(1), 1-8. https://doi.org/10.1016/j.eurpsy.2010.04.011

Koç, P. (2017). Internet Addiction and Subjective Well-Being in University Students, Journal of Positive Psychology and Wellbeing, 1(1).

Kratzer, S., \& Hegerl, U. (2008). Is "Internet Addiction" a disorder of its own?-a study on subjects with excessive internet use. Psychiatrische Praxis, 35(2), 80-83. https://doi.org/10.1055/s-2007-970888

Kutlu, M., Savci, M., Demir, Y., \& Aysan, F. (2016). Young İnternet Bağimliliği Testi Kisa Formunun Türkçe uyarlamasi: Üniversite öğrencileri ve ergenlerde geçerlilik ve güvenilirlik çalişmasi. Anadolu Psikiyatri Dergisi, 17(1), 69-76. https://doi.org/10.5455/apd.190501

La Greca, A. M., \& Lopez, N. (1998). Social anxiety among adolescents: Linkages with peer relations and friendships. Journal of abnormal child psychology, 26(2), 83-94. https://doi.org/10.1023/A:1022684520514

Lai, C. M., Mak, K. K., Watanabe, H., Jeong, J., Kim, D., Bahar, N., ... \& Cheng, C. (2015). The mediating role of Internet addiction in depression, social anxiety, and psychosocial well-being among adolescents in six 
Asian countries: a structural equation modelling approach. Public health, 129(9), 1224-1236. https://doi.org/10.1016/j.puhe.2015.07.031

Lam, L. T., Peng, Z., Mai, J., \& Jing, J. (2009). The association between internet addiction and self-injurious behaviour among adolescents. Injury prevention, 15(6), 403-408. https://doi.org/10.1136/ip.2009.021949

Lee, B. W., \& Stapinski, L. A. (2012). Seeking safety on the internet: Relationship between social anxiety and problematic internet use. Journal of anxiety disorders, 26(1), 197-205. https://doi.org/10.1016/j.janxdis.2011.11.001

Li, X., Buxton, O. M., Kim, Y., Haneuse, S., \& Kawachi, I. (2020). Do procrastinators get worse sleep? Cross-sectional study of US adolescents and young adults. SSM-Population Health, 10, 100518. https://doi.org/10.1016/j.ssmph.2019.100518

Machado, M-R., Bruck, I., Cat, M. N. L., Soares, M. C., \& Silva, A. F. (2018). Internet Addiction And its Correlation with Behavioral Problems and Functional Impairments-A Cross-Sectional Study. Jornal Brasileiro de Psiquiatria, 67(1), 34-38. https://doi.org/10.1590/0047-2085000000181

Malyshev, I., \& Arkhipenko, I. (2019). Interrelation between procrastination and Internet addiction in high school students in the context of risks of modern education. In SHS Web of Conferences (Vol. 70, p. 08030). EDP Sciences. https://doi.org/10.1051/shsconf/20197008030

McCord, B., Rodebaugh, T. L., \& Levinson, C. A. (2014). Facebook: Social uses and anxiety. Computers in Human Behavior, 34, 23-27. https://doi.org/10.1016/j.chb.2014.01.020

McIntyre, E., Wiener, K., \& Saliba, A. (2015). Compulsive Internet use and relations between social connectedness, and introversion, Computers in Human Behavior, 48, 569-574. https://doi.org/10.1016/j.chb.2015.02.021

Nalwa, K., \& Anand, A. P. (2003). Internet addiction in students: A cause of concern. Cyberpsychology \& Behavior, 6(6), 653-656. https://doi.org/10.1089/109493103322725441

Odaci, H., \& Çikrikçi, Ö. (2017). Problemli internet kullaniminda depresyon, kaygi ve stres düzeyine dayali farkliliklar. Addicta: The Turkish Journal on Addictions, 4(1), 41-61. https://doi.org/10.15805/addicta.2017.4.1.0020

Odaci, H., \& Kalkan, M. (2010). Problematic Internet use, loneliness and dating anxiety among young adult university students. Computers \& Education, $1091-1097$. https://doi.org/10.1016/j.compedu.2010.05.006

Ögel, K. (2012). Internet bă̆imliliği: Internetin psikolojisini anlamak ve băgimlilikla başa çikmak. İş Bankasi Kültür Yayinlari.

Ögel, K. (2014). Internet Bă̆imliliği İnternetin Psikolojisini Anlamak ve Bă̆imlilikla Başa Çikmak. 2. baski. İstanbul, Türkiye İş Bankasi Kültür Yayinlari.

Pawlikowski, M., Altstötter-Gleich, C., \& Brand, M. (2013). Validation and psychometric properties of a short version of Young's Internet Addiction Test. Computers in Human Behavior, 29(3), 1212-1223. https://doi.org/10.1016/j.chb.2012.10.014

Quinn, W. (2019). Academic procrastination: the role of stress, self-esteem, self-efficacy, age and gender on undergraduate students. https://esource.dbs.ie/handle/10788/3874

Radtke, S. R., Strege, M. V., \& Ollendick, T. H. (2020). Exposure therapy for children and adolescents with social anxiety disorder. In Exposure Therapy for Children with Anxiety and OCD (pp. 193-219). Academic Press. https://doi.org/10.1016/B978-0-12-815915-6.00009-3

Saddler, C. D., \& Buley, J. (1999). Predictors of academic procrastination in college students. Psychological Reports, 84(2), 686-688. https://doi.org/10.2466/pr0.1999.84.2.686

Sahin, Y. L. (2014). Comparison of users' adoption and use cases of Facebook and their academic procrastination. Digital. Education Review, 25, 127-138.

Schouwenburg, H. C., Lay, C. H., Pychyl, T. A., \& Ferrari, J. R. (2004). Counseling the procrastinator in academic settings. American Psychological Association. https://doi.org/10.1037/10808-000

Sela, Y., Zach, M., Amichay-Hamburger, Y., Mishali, M., \& Omer, H. (2020). Family environment and problematic internet use among adolescents: The mediating roles of depression and Fear of Missing Out. Computers in Human Behavior, 106, 106226. https://doi.org/10.1016/j.chb.2019.106226 
Shaughnessy, J. J., Zechmeister, E. B., \& Zechmeister, J. S. (2012). Observation. Research Methods in Psychology (9th ed.).

Shih, S. S. (2017). Factors related to Taiwanese adolescents' academic procrastination, time management, and perfectionism. The Journal of Educational Research, 110(4), 415-424 https://doi.org/10.1080/00220671.2015.1108278

Sirois, F. M. (2016). Introduction: conceptualizing the relations of procrastination to health and well-being. In Procrastination, health, and well-being (pp. 3-20). Academic Press. https://doi.org/10.1016/B978-0-12-802862-9.00001-3

Solomon, L. J., \& Rothblum, E. D. (1984). Academic procrastination: Frequency and cognitive-behavioral correlates. Journal of counseling psychology, 31(4), 503. https://doi.org/10.1037/0022-0167.31.4.503

Steel, P. (2007). The nature of procrastination. Psychological Bulletin, 133(1), 65-94. https://doi.org/10.1037/0033-2909.133.1.65

Şaşmaz, T., Öner, S., Kurt, A. Ö., Yapici, G., Yazici, A. E., Buğdayci, R., \& Şiş, M. (2013). Prevalence and risk factors of Internet addiction in high school students. The European Journal of Public Health, 24(1), 15-20. https://doi.org/10.1093/eurpub/ckt051

Tagay, Ö., Önen, Ö., \& Polat, İ. C. (2018). Ergenlerin sosyal kaygi düzeyleri ile güvengenlik ve özsaygilari arasindaki ilişki. Afyon Kocatepe Üniversitesi Sosyal Bilimler Dergisi, 20(2), 261-269. https://doi.org/10.32709/akusosbil.398991

Tahiroğlu, A. Y., Çelik, G. G., Bahali, K., \& Avci, A. (2010). Medyanin Çocuk ve Gençler Üzerine Olumsuz Etkileri; Şiddet Eğilimi ve İnternet Bağimliği. In Yeni Symposium (Vol. 48, No. 1). https://doi.org/10.4274/npa.y5662

Tang, C. S. K. (2018). Depression and Impulsivity Mediating the Relationship Between Social Anxiety and Internet Addiction. International Journal of Psychology \& Behavior Analysis, 2018. https://doi.org/10.15344/2455-3867/2018/141

Tarhan, N. (2012). Sen ben ve çocuklarimiz. Timaş Yayinlari.

Tassin, C., Reynaert, C., Jacques, D., \& Zdanowicz, N. (2014). Anxiety disorders in adolescence. Psychiatria Danubina, 26(1), 27-30.

Taylan, H. H., \& Işik, M. (2015). Sakarya'da ortaokul ve lise öğrencilerinde internet bağimliliği. Turkish Studies-International Periodical for the Languages, Literature and History of Turkish or Turkic, 10(6), 855-874. https://doi.org/10.7827/TurkishStudies.8286

Tian, Y., Si, Y., Meng, W., Bian, Y., Han, P., Hu, J., ... \& Gao, F. (2019). Mediating factors of the association between shyness and generalized pathological internet use in Chinese university students. International Journal of Mental Health and Addiction, 17(3), 555-572. https://doi.org/10.1007/s11469-018-9979-4

Tokunaga, R. S., \& Rains, S. A. (2010). An evaluation of two characterizations of the relationships between problematic Internet use,time spent using the Internet, and psychosocial problems. Human Communication Research, 36(4), 512-545. https://doi.org/10.1111/j.1468-2958.2010.01386.x

Tras, Z., Öztemel, K. (2019). Facebook Yoğunluğu, Gelişmeleri Kaçirma Korkusu ve Akilli Telefon Bağimliliği Arasindaki İlişkinin İncelenmesi. ADDICTA, 6(1), 91-113. https://doi.org/10.15805/addicta.2019.6.1.0063

Tras, Z., Öztemel, K., \& Baltaci, U. B. (2019). Role of Problematic Internet Use, Sense of Belonging and Social Appearance Anxiety in Facebook Use Intensity of University Students. International Education Studies, 12(8), 1-10. https://doi.org/10.5539/ies.v12n8p1

Uzun, Ö. B. (2009). Bir Grup Lise Öğrencisinde Akademik Erteleme Davranişi: Sikliği, Olasi Nedenleri ve Umudun Rolü. Türk Psikolojik Danişma ve Rehberlik Dergisi, 4(32), 12-19.

Ümmet, D., \& Ekşi, F. (2016). Türkiye'deki genç yetişkinlerde internet bağimliliği: yalnizlik ve sanal ortam yalnizlik bağlaminda bir inceleme. Addicta: The Turkish Journal on Addictions, 3(1), 29-53. https://doi.org/10.15805/addicta.2016.3.0008

Weidman, A. C., \& Levinson, C. A. (2015). I'm Still Socially Anxious Online: Offline Relationship Impairment Characterizing Social Anxiety Manifests and Is Accurately Perceived in Online Social Networking Profiles. Computers in Human Behavior, 49, 12-19. https://doi.org/10.1016/j.chb.2014.12.045

Weinstein, A., Dorani, D., Elhadif, R., Bukovza, Y., Yarmulnik, A., \& Dannon, P. (2015). Internet addiction is 
associated with social anxiety in young adults. Annals of Clinical Psychiatry, 27(1), 4-9.

Wretschko, G. (2006). Problematic internet use, flow and procrastination in the workplace (Doctoral dissertation).

Xin, M., Xing, J., Pengfei, W., Houru, L., Mengcheng, W., \& Hong, Z. (2018). Online activities, prevalence of Internet addiction and risk factors related to family and school among adolescents in China. Addictive behaviors reports, 7, 14-18 https://doi.org/10.1016/j.abrep.2017.10.003

Yang, Z., Asbury, K., \& Griffiths, M. D. (2019). An exploration of problematic smartphone use among Chinese university students: Associations with academic anxiety, academic procrastination, self-regulation and subjective wellbeing. International Journal of Mental Health and Addiction, 17(3), 596-614. https://doi.org/10.1007/s11469-018-9961-1

Yao, M. Z., \& Zhong, Z. J. (2014). Loneliness, social contacts and Internet addiction: A cross-lagged panel study. Computers in Human Behavior, 30, 164-170. https://doi.org/10.1016/j.chb.2013.08.007

Yavuz, O. (2018). Ergenlik döneminde internet bağimliliğinin okul başarisi üzerinde etkileri. OPUS Uluslararasi Toplum Araştirmalari Dergisi, 8(15), 1056-1080. https://doi.org/10.26466/opus.426914

Yayan, E. H., Suna-Dağ, Y., \& Düken, M. E. (2019). The effects of technology use on working young loneliness and social relationships. Perspectives in Psychiatric Care, 55(2), 194-200. https://doi.org/10.1111/ppc. 12318

Yen, C. F., King, B. H., \& Tang, T. C. (2010). The association between short and long nocturnal sleep durations and risky behaviours and the moderating factors in Taiwanese adolescents. Psychiatry research, 179(1), 69-74. https://doi.org/10.1016/j.psychres.2009.02.016

Yen, J. Y., Ko, C. H., Yen, C. F., Wu, H. Y., \& Yang, M. J. (2007). The comorbid psychiatric symptoms of Internet addiction: attention deficit and hyperactivity disorder (ADHD), depression, social phobia, and hostility. Journal of adolescent health, 4l(1), 93-98. https://doi.org/10.1016/j.jadohealth.2007.02.002

Yen, J. Y., Yen, C. F., Chen, C. S., Wang, P. W., Chang, Y. H., \& Ko, C. H. (2012). Social anxiety in online and real-life interaction and their associated factors. Cyberpsychology, Behavior, and Social Networking, 15(1), 7-12. https://doi.org/10.1089/cyber.2011.0015

Yilmaz, G., Şar, A., Civan, S. (2015). Investigation of Adolescent Mobile Phone Addiction by Social Anxiety Effect of Some Variable. Online Journal of Technology Addiction and Cyberbullying, 2(2), 20-37. Retrieved from https://dergipark.org.tr/tr/pub/ojtac/issue/28470/303439

Young, C. M. Y., \& Lo, B. C. Y. (2012). Cognitive appraisal mediating relationship between social anxiety and internet communication in adolescents. Personality and Individual Differences, 52(1), 78-83. https://doi.org/10.1016/j.paid.2011.09.001

Young, K. S. (1998). Internet addiction: The emergence of a new clinical disorder. Cyberpsychology \& behavior, 1(3), 237-244. https://doi.org/10.1089/cpb.1998.1.237

Yujia, R. E. N., Jiao, Y. A. N. G., \& Liqiong, L. I. U. (2017). Social anxiety and internet addiction among rural left-behind children: the mediating effect of loneliness. Iranian journal of public health, 46(12), 1659.

Yurdakoş, K., \& Biçer, E. B. (2019). İnternet Bağimlilik Düzeyinin Akademik Ertelemeye Etkisi: Sağlik Yönetimi Öğrencileri Üzerine Bir Araştirma. Yüzüncü Yil Üniversitesi Eğitim Fakültesi Dergisi, 16(1), 243-278. https://doi.org/10.23891/efdyyu.2019.125

Zorbaz, O. (2013). Lise öğrencilerinin problemli internet kullaniminin sosyal kaygi ve akran ilişskileri açisindan incelenmesi (Master's thesis, Sosyal Bilimler Enstitüsü).

\section{Copyrights}

Copyright for this article is retained by the author(s), with first publication rights granted to the journal.

This is an open-access article distributed under the terms and conditions of the Creative Commons Attribution license (http://creativecommons.org/licenses/by/4.0/). 